\section{"Unsettling Con-sequence"}

John J. Joughin \& Simon Malpas (ed.), The New Aestheticism (Manchester \& New York: Manchester University Press, 2003)

Instead of a complacent discourse about so far accepted aesthetic verities, new aestheticism presents a fundamental challenge to old-style aesthetics, that is, the politically impregnated, grossly reductive, elitist modes of committed theoretical criticism. As the introductory passage by the editors, John J. Joughin and Simon Malpas, says, the attribute "new" implies that the former aesthetic theories have no longer validly registered the tensions and alterations in contemporary society and have failed to exploit aesthetics' essential critical potential concerning culture, since the notion of art has been mistakenly simplified as an "apolitically humanist," "benign" activity. During the mid-1990s, though, coinciding with the emergence of a 'posttheoretical' approach, new aestheticism already marked the end of the initial cycle of critical theorization and the aggrandizement of a more reflective aesthetics could finally begin.

The present collection of thirteen essays, divided into the three main parts "Positions," "Readings" and
"Reflections," however different queries they might address, unanimously wish to restore what has been overlooked in the analysing process: the fact that art, despite being underpinned by popular rather than high culture, and being contaminated by politics and a priori localized schemes of judgement, has an inalienable intrinsic spiritual value existing separately from the knowledge we only think to possess concerning art.

The new aesthetes want to see the act of decoding art as "pure potentiality" or as spontaneous "dance": mobile, playful, "unchoreographed" (Thomas Doherty, "Aesthetic Education and the Demise of Experience") and not as if art was a mere cultural commodity that feeds on the dicta of a fragmentary world torn apart by plurality and where it can only be one among the numerous needs of the spirit of the age (Simon Malpas, "Touching Art: Aesthetics, Fragmentation and Community"). Therefore, the main wave of argument running through the essays relies exactly on the wish to liberate the ready-made theoretical perspective and metaphoric ability with which we conceive of art before the individual's actual encounter with it.

The dispute for the inheritance of the Western philosophical tradition and within it for the role of aesthetics, 
is rekindled by Joanna Hodge's essay, "Aesthetics and Politics: between Adorno and Heidegger" on two critically polar philosophers' notion of historicality, conceived of as "elliptically oscillating" between aesthetics, politics, artworks and political history. It follows that art, being the artist's response to reality, is seen as 'making' or as a form of cultivating the specific culture it is embedded in. Art, concerning both its birth and afterlife, involves reflective critical judgement uncovering the law of the work of art and relating it to the thought of responsibility, morality and law on a larger scale. Thus, the ultimate end of new aesthetic criticism is the purpose of connecting the work of art to the formation of culture, which requires the involvement of the artist with history (Gary Banham, "Kant and the Ends of Criticism").

Contemporary works of art, engaged with the contemporary politics of art, can be also approached through the notion of "inclusion," mostly considered to be an ineliminable possibility of interpretations, a "reiteration of sameness" in spite of every artefact being different. Inclusion also entails "negotiation" concerning art's reception and "has the structure of a decision." The opposite of inclusion is "transforma- tion," which identifies a sociopolitical possibility, hence art seen in the light of transformation is either "utopian or outmoded," therefore transformation is "replaced by strategies either of adaptation or of denial." Due to the contrast of the two terms and their connotations, the work of art becomes and remains the site of incessant contestation depending on interpretation and the politics of criticism (Andrew Benjamin, "Including Transformation: Notes on the Art of the Contemporary").

Clearly seeing the historical and cultural advancements of contemporary society, Part I of the compilation, entitled simply as "Positions," encourages the reader to re-construe the critic's essential role in the act of determining the reception of art, and thus we are confronted with the legitimate question whether our appropriation of art is mere self-justifying "knowingness" instead of "nonconceptual" openness ready to accept a plethora of possible interpretations.

The overarching essay "What Comes after Art?" by Professor Andrew Bowie presents a most genuine and brave attack on the aesthetic imperative. Bowie does not let us settle in the comfortable position that art cannot possibly exist without our philosophy and pronouncements. Accordingly, new aestheticism wel- 
comes the phenomenon that contemporary aesthetics is aware of, and reflective on, oppositional (e.g. feminist or racialised) art. Oppositional art, in order to compensate for the "disembodied forms of political power" and subversion, performs a "slippage of identification" or "masquerade" and hides its forgotten "prehistorical and libidinal" vein that might easily be suffocated, simply because "art in opposition" is always a potential threat or an unusual attraction of a yet uncomprehended sphere (Ewa Plonowska Ziarek, "Mimesis in Black and White: Feminist Aesthetics, Negativity and Semblance").

To faithfully represent the theoretical path clearly set by "Positions" and its organic continuum, "Reflections," the five essays of "Readings" help us to successfully test the new aesthetic tool of interpreting a unique literary text. Howard Caygill's "The Alexandrian Aesthetics," for instance, analyses the experience of allegory in the Alexandrian diaspora, which was hospitable towards cultural differences, and thus became the paradoxical scene of aesthetic pleasure and ascetic reason in the poetics of Giuseppe Ungaretti and C. P. Cavafy. The author of the second essay, Mark Robinson, in his "Defending Poetry, or, Is There an Early Modern Aes- thetic?" is dissatisfied precisely with the characterisation of the English Renaissance and the Tudor period as 'early modern,' and dissects the ambivalence by pointing out that the connotations of the concept 'modern' are 'instrumental,' 'rational,' 'powerful' and 'autonomously subjective,' which are meanings the word 'modern' gained rather in the 18 th century. Robson shows that the term 'early modern,' from the 16th-17th-century point of view, thus reveals itself as an indefinable, semantically empty phrase without a firm critical or aesthetic value and it is unable to indicate that art in 'the Renaissance' was not alienated from truth and morality and was not a mere parasitic imitation of reality. As far as the word 'early' is concerned, Robson suggests that it is also unsuitable, since it implies that art then had no connection with the narrative of history upon which cultural poetics and historicism depend.

The Renaissance and its contemporary treatment in adaptations is a popular and fascinating topic today. In line with that, J. J. Joughin's "Shakespeare's Genius: Hamlet, Adaptation and the Work of Following" is another interesting attempt to bring us closer to Shakespearean drama. Joughin derives the definition of 'genius' from the Kantian paradigm 
and shows that the term, which played a significant role in setting the criteria for modern aesthetics, carries the primary semantic weight of "exemplary" and "originary." Paradoxically enough, Joughin argues, the art of a genius "reveals" both "compliance with and deviation from" the standard measures of formal aesthetics, and this is the source of the artist prodigy's "indeterminacy" and "proto-political and ethical nature." Joughin believes that Hamlet possesses the features of such a genius; Hamlet "ad-justs himself, i.e. moves towards justice" to reveal truth via the Mousetrap scene. The play within the play thus presents the critical event, the hermeneutic encounter and responsible ethical reflection upon the 'other' that can only be imagined but never accurately known. Such an event is adaptation itself, allowing for the creation of alterity (be it a phantom, an apparition, or a ghost) through the conscious displacement of the reader's own conceptual context, and never through a simple comparison.

In the trenchantly sensitive essay, "Melancholy as Form: Towards an Archeology of Modernism," Jay Bernstein analyses melancholy as the form of the secular-transcendental modernist novel, where a "roman without Bildung," the dialectic of spleen and ideal, the entanglement of beauty and decomposition unfolds, repels or attracts in equal measure. The philosophy behind the modernist work of art is to integrate dissonance, pain and suffering simultaneously with their contrastive values. The author's excellent demonstrative example thereof is Philip Roth's "American Pastoral," which marks both the evaporation of the myth of American beauty and the all-devouring beginning of urban decay.

"Critical Knowledge, Scientific Knowledge and the Truth of Literature" by Robert Eaglestone expertly describes art's inevitable connection to the most important ethical questions, demonstrating that art knows an "untaxonomized" truth or aletheia - 'uncovering,' 'disclosure' - that constantly "defamiliarises" the world in our eyes and (re-)teaches who and how we are. Placed on this moral ground, the new aesthetic reading of Joseph Conrad's "Heart of Darkness" purports to show the method of closely attending to the 'rhythms' of art, which is the most primary intention of the eloquent essays in the whole book.

"The New Aestheticism" refuses to be another theoretical authority unshakably confident of the righteousness of its interpretative means, since it is far too aware of the fact that for- 
mer theories, like cultural criticism for instance, also "threatened the firm distinction between the theory per se and their particular textual articulation." What it wants, however, is both to encourage critical discourse and to open a more reflective phase in criticism, irreducible to the exclusive political, historical and ideological commitments of contemporary society and to understand the truthpotential of art in its unique "artness." Thus, it is a major challenge, among the contemporary trends of literary interpretation, to 'new historicism' and 'cultural materialism.' How will these two paradigms respond, similar also in being equally powerful both in Britain and the
United States? Will they respond at all, or will they try to allow new aestheticism to 'slip by' (as perhaps they did with 'ethical criticism')? Will they offer inclusive 'negotiations,' trying to show that they have 'always' wanted the 'same thing?' Will the openness, the flexibility and the adaptability of the new aestheticism expedite its 'blending' with other paradigms, perhaps precisely with new historicism and cultural materialism? The next few years will undoubtedly decide these questions and the reviewer is surely not alone in wishing for a genuine and substantial debate, and in hoping for a 'Copernican turn' in literary criticism.

Móni Kálmán 